\title{
Typhus, yellow fever and Medicine in Mexico during the French intervention
}

Monserrat Gerardo-Ramírez¹, Jesús Zavaleta-Castro² and Luis Enrique Gómez-Quiroz

${ }^{1}$ Department of Health Sciences, Universidad Autónoma Metropolitana Iztapalapa, Ciudad de México; ${ }^{2}$ Instituto Estatal de Documentación de Morelos, Cuernavaca, Mor., Mexico

\begin{abstract}
French intervention in Mexico (1861-1867) is particularly full of episodes of patriotic heroism in terms of military, politic and, even, religious affairs, however this history is also rich in episodes related to diseases and the evolution of Mexican scientific medicine practice, epidemics such as typhus (nowadays knows as rickettsiosis), yellow fever, or cholera. Principally, this context outlined the Mexican history and influenced the course of the nation. The epidemics served as fertile land for the development of medicine science leading by prominent physicians, particularly by doctor Miguel Francisco Jiménez.
\end{abstract}

KEY WORDS: Typhus. Yellow fever. French intervention. General Zaragoza. Maximilian of Habsburg.

\section{Introduction}

"Immense, extremely painful, perhaps irreparable, is the loss just suffered by the Republic", expressed Francisco Zarco that Saturday at the San Fernando Cemetery, before Ignacio Zaragoza's grave. Five days before, the morning of September 8, 1862, the hero of the $5^{\text {th }}$ of May battle had died as a consequence of typhus. After his victory over the French troops in Puebla, he contracted the disease when he passed by the Acultzingo Peaks, where he had paid visit to wounded and sick soldiers. General Zaragoza was assisted by Doctor Juan N. Navarro, who had been expressly sent by President Benito Juárez, and expired in the presence of his mother and one of his sisters ${ }^{1}$,

Four months prior, on May 5, Zaragoza had informed about the victory of the Mexican army over the invading forces in Puebla. On the military briefing, he highlighted "the behavior of my brave comrades", since "the glorious event that just has taken place shows their spirit and, by itself, recommends them" as patriots. When referring to the French army, he recognized that it "has fought with great bravery", in spite that "its general in chief has behaved awkwardly in the attack" to the city of Puebla. "National arms [...] have covered themselves with glory", concluded Zaragoza².

The period encompassed by the French intervention, since the landing of the European troops (1861) until Maximilian of Habsburg execution (1867), is with no doubt one of the most fascinating in the country's history. Beyond the warlike and political part, the presence of several diseases, such as typhus and yellow fever, shaped our nation; ironically, it is also a period where Mexican medicine arises with scientific bases thanks to French medicine.

\section{Typhus}

The year before the French intervention, Benito Juárez García, as president of the Republic, had issued the Foreign Debt Suspension Decree (July 17,

\author{
Correspondence: \\ Luis E. Gómez-Quiroz \\ Departamento de Ciencias de la Salud \\ Universidad Autónoma Metropolitana Iztapalapa \\ Av. San Rafael Atlixco, 186 \\ Col. Vicentina, Del. Iztapalapa \\ C.P. 09340, Ciudad de México, México \\ E-mail: legq@xanum.uam.mx
}

Date of reception: 02-11-2016

Date of acceptance: 02-11-2016

DOI://dx.doi.org/10.24875/GMM.M18000119
Gac Med Mex. 2018;154:88-93

Contents available at PubMed www.gacetamedicademexico.com 
1861), by means of which he cancelled "for a term of two years all payments, including those assigned to the debt contracted in London and to foreign conventions" ${ }^{\prime \prime}$. The rejection to this provision by the English and French governments was immediate, with the Spanish government joining in. As a consequence, on October 31, the Tripartite Convention was signed in London, which implied the shipment of "combined sea and land forces" to the Mexican territory in order to force it to pay its debts ${ }^{3}$.

Typhus is a disease that caused many problems in Mexico throughout its history. It is caused by a very particular type of bacteria of the rickettsia family, which was precisely discovered in Mexico by Doctor Howard Taylor Ricketts during the 1909 epidemic (Fig. 1), and that was to cause his death by the disease he was studying in May $1910^{4}$. The bacterium is transmitted by infected lice that excrete the microorganism in the feces, which is introduced in the wound left by the insect when the person scratches him/ herself as a consequence of the bite.

The word "typhus" derives from Greek typhus, which means "stupor". It is an infectious disease caused by bacteria such as Rickettsia typhi or Rickettsia prowazekii that often is mistaken with typhoid fever, which is caused by other bacterium, Salmonella typhi. In those times, there was much confusion and patients were often misdiagnosed, until Dr. Jiménez made it clear, as will be later explained.

It's not hard to imagine the scenario in the country for these epidemics to occur: overcrowding, poverty and lack of hydric and hygienic resources made for the disease to considerably spread. As previously mentioned, these were, to a large extent, the conditions prevailing in the country even before the Frenchmen arrival, and which worsened during the interventionist period.

The advance of epidemics may have worsened perhaps by the natural chaos caused, administratively, by the Reform Laws; for example, in February 1861, President Juárez decreed the secularization of hospitals and welfare establishments, which had been managed by the Catholic Church until then, and at the same time, to put order in these services, already in hands of the State, the Directorate General of Public Welfare Funds was created as a branch of the Ministry of the Interior. The institutions that were left under the control of this directorate included the Divino Salvador Hospital and La Cuna foundling house, and many other hospital institutions that one way or another were administered by the Church with experience ${ }^{5}$.

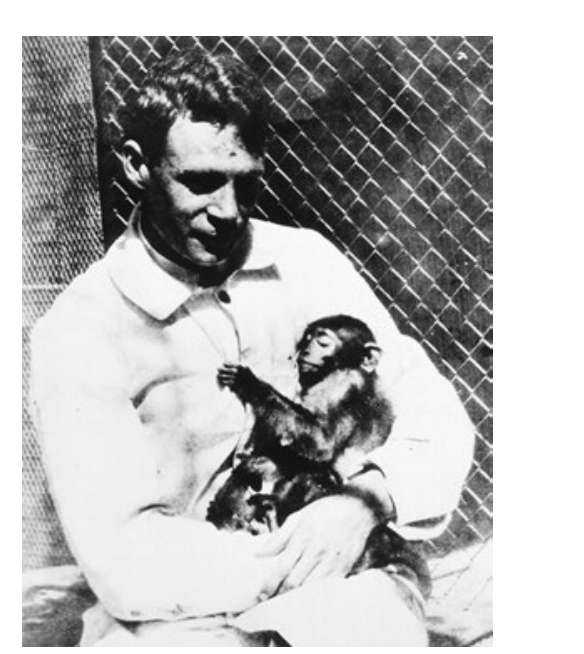

Figure 1. Picture of Doctor Howard Taylor Ricketts with one of his experimental animals (The National Library of Medicine, $\mathrm{NIH}$ ).

The relationship between lack of economic resources and the development of the disease can have, perhaps, as the greatest example, General Ignacio Zaragoza's own contagion and death.

Both in Mexico City and in Puebla, cases of typhus occurred in 1848 and continued in 1849. The disease spread from 1857, the year the Liberal Constitution was published, with Ignacio Comonfort being president of the Republic, to 1859. The same happened in 1861,1862 (year of the $5^{\text {th }}$ of May Battle) and 1867 (year of the $2^{\text {nd }}$ of April Battle), as a consequence of "movements of military and civilian groups in conditions of insufficient hygienic means", which affected the Mexican troops that had been victorious in Puebla. Not only General Zaragoza, but also "many of his soldiers" and officers died as typhus victims.

After the victory of the Eastern Army over the French troops, communication between General Zaragoza and President Juárez was constant; there was no telegram in which General Zaragoza didn't ask for economic resources for the support of the army, not only in terms of food supplies, but also for the care of endemic diseases that, together with the invading army, attacked the national troops.

The inhabitants of the city of Puebla, far from cooperating, represented a certain obstacle. Such was the case that General Zaragoza himself reported on May 9: "this execrable city that I have not set on fire because there are innocent creatures in it... As for money, there is nothing to be done here, because these people are mean in general, and especially very indolent and selfish... Burning Puebla would be a good thing. It is in mourning due to the event of the $5^{\text {th }}$. It's sad to say this, but it is a shameful truth". Terrible the 
report given by the General about heroic Puebla inhabitants' attitude.

On September 1, 1862, General Zaragoza started experiencing symptoms of the infection, particularly high fever, and he was therefore sent to his station in Puebla. A few months before, he had received his daughter's visit, and his wife had died early that same year, to whom he could only provide with 100 pesos for her support, enough for 3 days, which can show the economic situation of the general, and therefore, of the entire Eastern Army. Ignacio Zaragoza died on September 8, 1862, at the age of 33 years, as a consequence of rickettsiosis or typhus ${ }^{7}$, which interrupted the General's brilliant career, which with no doubt could have given even much more to the nation.

"The [federal] government considers General Zaragoza's unexpected death to be a public misfortune", wrote Enrique de Wagner, minister of Prussia in Mexico. "After some days of illness, Zaragoza died of typhus in Puebla, where this epidemic wreaks great havoc, as well as in the entire zone comprised between this city and Orizaba." The Prussian diplomat warned that the French army would be exposed "to great dangers in case of taking the route of all these infested villages and cities", and recommended for "the majority of the forces to be mobilized through Jalapa and Perote, Huamantla, Otumba or San Martín", with the city of Puebla remaining under the protection of "a few thousand men"8.

Interestingly, rickettsioses are constant in warlike processes. In the 1480-1490 Spanish civil war, Christian and Moor troops are known to have been decimated by disease, while similar effects were caused in Napoleon troops in 1812, whereas in World War I, around 100,000 cases occurred in 1914 and 15,000 in $1916^{9}$. Disease was also key in the plans for Jews elimination in the countries controlled by Nazi Germany, an aspect that is masterfully addressed in Dr. Naomi Baumslag's work ${ }^{4}$.

\section{Yellow fever}

Yellow fever is a disease caused by a virus of the arbovirus family, of the Flavivirus genus, and is transmitted by infected mosquitoes, such as Aedes aegypti (Fig. 2). The disease is characterized by high fever and severe liver damage, which generates jaundice in patients, and hence the term "yellow fever". Once again, a lack of sanitation in contaminated water containers is essential for the reproduction of the mosquito. The disease is currently relatively controlled thanks to

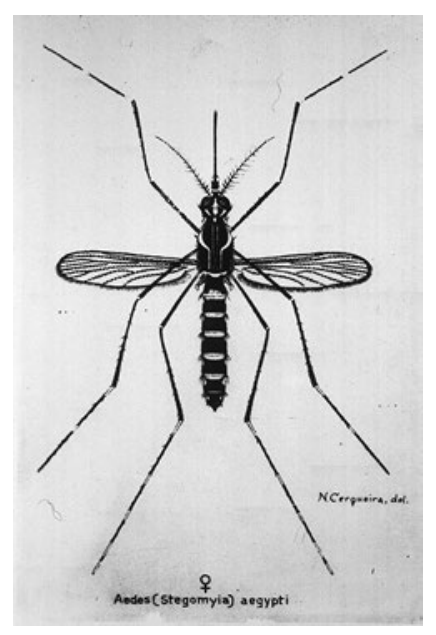

Figure 2. Classic representation of an Aedes (Stegomya) aegypti mosquito (The National Library of Medicine, $\mathrm{NIH}$ ).

vaccines and effective treatments, but in times of the French invasion this wasn't even imagined of.

Yellow fever, or yellow plague, was something that considerably worried invading armies. One of the first reports of this disease, also known as yellow jack, is referred by Jena-Jaques Ampère ${ }^{10}$, when stating that in Mexico there are two completely unbearable things: "la fièvre jaune et les brigands". Ampère's report is overwhelming: "one of the worst inconveniences (is yellow fever)"11.

Spaniards who had first arrived to the Gulf of Mexico coasts were the first victims of this disease, endemic of that region. General Juan Prim, the Spanish commander, a few weeks after having landed, sent around 800 soldiers to hospitals in Cuba for their care. Perhaps President Juárez took advantage of that "natural defense" and played with negotiation time, hoping for the disease to be a natural ally.

The negotiation resulted in the invaders being allowed to advance towards Orizaba, located at 2800 meters above sea level, where the mosquito hardly subsisted. When Spaniards and Englishmen noticed French intentions, they retired and sailed back to their countries, but as previously mentioned, French troops did not.

In 1963, Gloria Grajales published, in the Historia Mexicana journal, quotes from documents of the archive referring the intervention in Mexico by England, France and Spain, which are preserved in the Public Record Office in London. She particularly quotes those related to the French intervention (classification F.O. 97/278, Vol. I, and 97/279, Vol. II, with the title French Expedition) ${ }^{12}$. In said report, at least three entries can be read making reference to the yellow fever 
and to the difficulties the French had to deal with this problem. The first reference, with no date, but reported around August 1862 says: "No date - Arrival of 300 sailors in the Iphigenia frigate; yellow fever contagion in Veracruz" (F.O. 97/278, I, p. 97). Later it refers: "December 4, 1862 - Johnson to Count Russell (No. 1347): About mortality among French troops caused by yellow fever; recruiting of thousand Egyptian blacks to serve in expeditionary forces in Mexico (F.O. 97/278, I, p. 187). And then: Paris, January 6, 1863 - Johnson to Count Russel (No. 20, confidential): About possible reasons to send reinforcements to Mexico, to cover losses caused by disease and death (1500 soldiers and 62 officers dead). Confidential information obtained through captain Hore. Measures taken by the French government to defray the costs of the expedition, etc." (F.O. 97/278, I, pp. 213214). "Memorandum annexed to the previous document: Data obtained through Mister Xavier Raymond about the state of the French army in Mexico. Strong losses caused by yellow fever and other diseases. Roads in bad shape, need for transportation for the Tampico expedition. Monthly expenses for land transportation in Mexico are insufficient. Raymond thinks that the feeling against the expedition is unanimous, etc." (F.O. 97/278, I, pp. 216-218).

The French army was clearly decimated by losses and deaths caused by yellow fever, but information was kept confidential, perhaps in an attempt not to increase the victorious feelings in Mexican troops. Although yellow fever affected the invaders, it did not cause for them to ultimately miss their objective, at least temporarily.

\section{Veracruz, Maximillian and yellow fever}

"Veracruz is a filthy and narrow city, famous for its terrible weather and extreme heat", stated Count Carl Khevenhüller-Metsch, a member of the Austrian volunteer corps that arrived to Mexico to accompany Maximillian of Habsburg. After 3 weeks of journey on the Floride ship, more than 800 men arrived to the Veracruz port on December 7, 1864, where they had to endure $44 \stackrel{\circ}{\circ} \mathrm{C}$ at night. Khevenhüller met "German and Austrian doctors who have to be paid the highest homage for their abnegation in times of the yellow fever, this terrible disease that snatches life in a few hours"13. On next day, they continued their journey to the capital of the country, afraid of contagion, given the insalubrious conditions of the port.
On Saturday May 8, 1863, the Novara ship, where Maximillian of Habsburg and his Wife Charlotte of Belgium and their court arrived, dropped anchor in the port of Veracruz. At $4 \mathrm{~h}$ in the morning of Sunday 29, everything was ready "to immediately continue the journey towards the capital, since a prolonged stay in Veracruz was not recommendable, owing to the yellow fever prevailing on that city, which is said to be especially dangerous for those recently arrived"14, stated Wilhelm Knechtel, official botanist of the emperor. However, 2 years later the emperor was to fall ill, with the care of a Mexican specialist being required to treat him.

Maximillian was "affected from the liver and in addition he had been suffering intermittent fevers contracted in one of the trips to warm lands"15. Friedrich Semmeleder, personal doctor of the Austrian, not knowing "too well the special treatment for [these] intermittent fevers", proposed the emperor to "consult with any of the local Mexican physicians who perfectly knew the treatment" against them. He was attended to by the physician Rafael Lucio, "who in those days was already an eminence". Initially, Lucio had resisted to that because "he was a staunch liberal and completely opposed to the imperial regime". Prior to leaving to Cuernavaca, Maximillian wanted to "settle his account with his Mexican doctor, [...] but the wise doctor completely refused receiving a single peso, claiming that having earned the Sovereign's gratitude sufficed him"14.

During the $19^{\text {th }}$ century, yellow fever, typhus, cholera, measles, plague and smallpox epidemic outbreaks added up to more than 70 in the State of Veracruz. Diseases attacked both cities and small villages, with not few of them being decimated. Although yellow fever epidemics were among the most common, "deaths were quantitatively fewer than with smallpox" After 1826 and 1855, 3 yellow fever epidemics occurred in a 5-year period: 1842,1843 and 1847, the latter in the year of the North American intervention. Between 1850 and 1852 there was another outbreak of the disease, as well as during the French intervention in 1863 and 1867. "Public health in the Veracruz territory [as in other regions in the country] walked hand in hand with the weather and with internal and international fights in defense of sovereignty"16.

\section{State of medicine during the French intervention}

Ironically, the existence of multiple epidemics (in 1864, life expectancy of Mexicans was estimated 
to be 30 years) ${ }^{5}$ was accompanied by fundamental events in the history of medicine during the period the country was occupied by France (1862 to 1867).

On April 18, 1864, the Scientific, Literary and Artistic Commission was founded, and on the $30^{\text {th }}$ of that month, the first meeting of the Medical Sciences Section (later National Academy of Medicine) was carried out. The section was divided in 5 sub-sections: pathology, hygiene, legal medicine and medical statistics, veterinary medicine, medical matters and pharmacology, and physiology and anthropology. The chair was in hands of Doctor Carlos Alberto Ehrmann, and vice-chair was in charge of Doctor Miguel Francisco Jiménez, who was professor at the National School of Medicine. Among other illustrious physicians of those days who were members of the section, Dr. Rafael Lucio and Dr. José María Vértiz can be mentioned ${ }^{17}$. As already mentioned, this time period is with no doubt one of the greatest as regards exemplary physicians and scientists; in addition to the above list, Doctors Lauro Jiménez and Leopoldo Río de la Loza, who made important contributions to pharmacology, should be mentioned, among others.

One of the main accomplishments of the medical section was the publication of Gaceta Médica de México, journal of the scientific commission medical section, which later would be simply Gaceta Médica de México, as until currently is known. The first issue appeared on Thursday September 15, 1864, with its first chairman being Dr. Miguel Francisco Jiménez.

In the first issue, differences between typhus and typhoid fever are precisely discussed in an article written by Dr. Jiménez himself, mentioning that it is an endemic disease in the country and clearly establishing its importance.

\section{Dr. Miguel Francisco Jiménez, amebic hepatic abscess and Mexican scientific medicine}

Dr. Miguel Francisco Jiménez (Fig. 3) is a clear example of growing medical science in the Mexico of the Empire. He was an intelligent and educated man who strongly supported rational and scientific medicine, taking observation, rather than guessing as a basis; he was a strong follower of Auenbrugger and Laennec contributions; he was with no doubt a physician ahead of his time, who applied a scientific view to clinical training and to the entire practice of medicine.

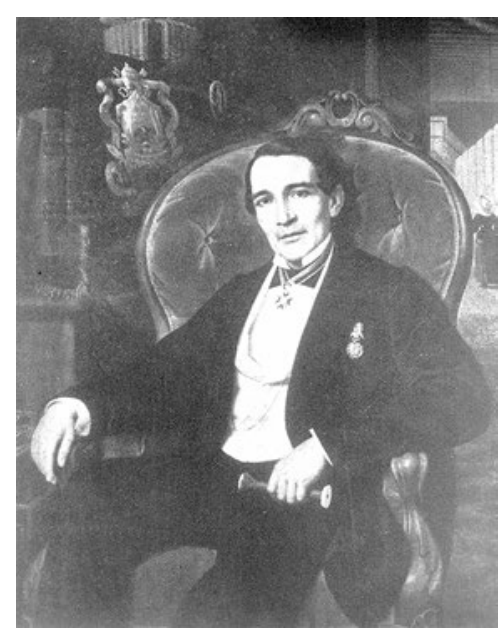

Figure 3. Doctor Miguel Francisco Jiménez.

He was born in Amozoc, Puebla in 1813. He graduated as a physician in 1838 at the Establishment of Medical Sciences, and almost immediately he occupied a post as a professor of pathology, and subsequently anatomy, teachings he offered until his death ${ }^{18}$.

In addition to the studies he carried out to distinguish between typhus and typhoid fever, he did research on other diseases that considerably afflicted the country's population, amebic hepatic abscess, which was very common in Mexico, even since the $16^{\text {th }}$ century.

Amebic hepatic abscess is an accumulation of pus in the liver as a response to the presence of Entamoeba histolytica. The disease is acquired by ingesting water or food contaminated with fecal matter. Once again, the high incidence of this disease speaks of overcrowding, poverty and of the unhealthy conditions of those days. Patients with the disease died regularly, even due to unfortunate medical interventions where a sickle-shaped blade knife was used without anesthesia or asepsis for the treatment not only of hepatic abscess, but for any type of abscess. If the patient didn't die from the disease, he/she died due to infection. This was common until the advance proposed by Dr. Jiménez, consisting in directly surgically intervening by means of a puncture to drain the abscess, which prevented its rupture and dissemination to other organs. It is not hard to imagine that this procedure saved lives and made for patients with the disease to have a better prognosis ${ }^{19}$.

Dr. Jiménez high professional and scientific level deserved the recognition of Maximillian of Habsburg, who invited him to join as one of his personal doctors, together with doctors Federico Semeleder, Samuel Basch and Rafael Lucio Nájera. 
Dr. Jiménez really thought that the arrival of the Empire was something good for the country, not in the plane of conservative exacerbation or apology of the monarchy, but he thought that a new national order could be established that would make the country move towards a better quality of life. In a letter he sent to José María Iglesias he mentions: "I am faithful that a new order could be founded which, being really accepted by everyone, would end once and forever the eternal anarchy that consumes us". Dr. Jiménez died in Mexico City in 1876.

\section{Conclusion}

The period of the French intervention has been one of the most convulsive epochs for the nation, since beyond the armed conflict and occupation, an economic, political and social disaster was experienced, which made for many of the public health problems to be exacerbated, thus affecting all and sundry, as we have seen. However, this is also period of time that marks the beginning of a revolution in medical science in our country by notorious physicians, and although not all of them have been mentioned, we have taken Dr. Francisco Jiménez example as a faithful representative of that generation of medical physicians who, interestingly, were trained in the French school of medicine. Finally, it was also on that period (Thursday September 15, 1864) that Gaceta Médica de Medicina started being published.

\section{Acknowledgements}

This work has been written for diffusion and divulgation purposes and had the support of CONACYT
Ciencia Básica No. 252942, Fronteras de la Ciencia 2015 No. 1320, Instituto Estatal de Documentación del Estado de Morelos and Universidad Autónoma Metropolitana Iztapalapa.

\section{References}

1. Gonzales Lezama R. Del triunfo republicano a la crisis política de 1861. El peor año de la república. Relatos e Historias en México. 2012;45:48-54.

2. Zaragoza I. Parte de Guerra del General Zaragoza. Relatos e Historias en México. 2012;4:68.

3. Porte Petit JM. Antecedentes de la intervención. Primer Congreso Nacional de Historia para el Estudio de la Guerra de Intervención, 1963. Sociedad Mexicana de Geografía y Estadística; 1963.

4. Baumslag N. Medicina asesina. Médicos nazis, experimentación con humanos y tifus. Barcelona: Plataforma Editorial; 2014.

5. Concheiro AA. Cronología médica mexicana. Cinco siglos. México: Siglo XXI; 2010.

6. Florescano E, Malvido E. Ensayos sobre la historia de las epidemias en México. Vol. 1. Instituto Mexicano del Seguro Social; 1982.

7. Rosas A. El patriotismo de Ignacio Zaragoza. Paisaje de la batalla. Relatos e Historias en México. 2012;45:71-6.

8. Díaz L. Versión francesa de México. Informes diplomáticos. 1862-1864. Vol. 3. El Colegio de México; 1965.

9. Peterson RKD. Insects, disease, and military history. The Napoleonic campaigns and historical perception. American Entomologist. 1995;41:147-61.

10. Ampère JJ. Promenade en Amérique. Etats-Unis-Cuba-Mexique. 2 ed. Vol. II. Paris: Michel Levy Freres; 1860.

11. Helguera MM. Posibles antecedentes de la intervención francesa. Historia Mexicana. 1965;15:1-24.

12. Grajales G. Intervención francesa y segundo imperio. Historia Mexicana. 1963;13:284-316

13. Hamann B. Con Maximiliano en México: del diario del príncipe Carl Khevenhüller, 1864-1867. México: FCE; 1992.

14. Knechtel W. Las memorias del jardinero de Maximiliano. Apuntes manuscritos de mis impresiones y experiencias personales en México entre 1864 y 1867. México: Instituto Nacional de Antropología e Historia; 2012.

15. Blasio JL. Maximiliano íntimo. El emperador Maximiliano y su corte. Memorias de un secretario particular. México: Librería de la Vda. de C. Bouret; 1905.

16. Aguilar Sánchez M, Ortiz Escamilla J. Historia general de Veracruz. México: Gobierno del Estado de Veracruz; 2011.

17. Rodríguez Pérez ME. De la Sección Médica a la Academia de Medicina de México: 1864-1880. En: La Academia Nacional de Medicina de México. 150 años de actividad ininterrumpida. México: Intersistemas editores, CONACYT; 2014

18. Martínez Guzmán M. Cuatro médicos personales del emperador Maximiliano de Habsburgo. 1864-1867. Boletín Mexicano de Historia y Filosofía de la Medicina. 2003;6:17-22.

19. Fernández del Castillo F. El tratamiento de los abscesos hepáticos antes del doctor Miguel Francisco Jiménez. Gac Med Mex. 1957;87:395-410. 